PROCEEDINGS OF THE

AMERICAN MATHEMATICAL SOCIETY

Volume 132, Number 10, Page 3133

S 0002-9939(03)07014-X

Article electronically published on May 22, 2003

\title{
FULL IDEALS IN REGULAR LOCAL RINGS
}

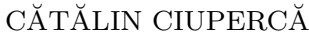

(Communicated by Bernd Ulrich)

Abstract. Paper withdrawn by author after original electronic posting date of May 22, 2003 and prior to preparation of the printed issue.

Department of Mathematics, University of California, Riverside, California 92521

E-mail address: ciuperca@math.ucr.edu

Received by the editors July 8, 2002 and, in revised form, September 5, 2002.

(C)2003 American Mathematical Society 